The Editors of the Proceedings of the Nutrition Society accept no responsibility for the abstracts of papers read at the Society's meetings for original communications.

\author{
PROCEEDINGS OF THE NUTRITION SOCIETY
}

\title{
ABSTRACTS OF COMMUNICATIONS
}

The Four Hundred and Thirty-third Meeting of the Nutrition Society was held in the Royal Society of Medicine, I Wimpole Street, London on Wednesday, ro December 1986, when the following papers were read: 
Smoking habit, carboxyhaemoglobin level and obesity in patients with peripheral arterial disease. By M. S. Sian, and R. M. Greenhalgh, Department of Surgery, Charing Cross Hospital and Westminster Medical School, London W6 8RF

The risk of smoking and its association with peripheral arterial disease is well established (Greenhalgh et al. 1981). Obesity is also a risk factor that should be considered in patients with arterial disease and there is evidence to suggest that severe obesity can lead to increased risk of complications in surgical patients (Garrow, I98I).

The level of carboxyhaemoglobin ( $\mathrm{HbCO}$ ) in the blood is a good index of smoking habit and distinguishes smokers from non-smokers. It has been monitored routinely in our patients with arterial disease and we have examined the prevalence of obesity in patients visiting the arterial-disease clinic over a period of 2 months. Blood samples from roo patients attending the clinic were analysed. $\mathrm{HbCO}$ was determined using an automated spectrophotometer IL $\mathbf{2 8 2}$ (Instrumentation Laboratory, Cheshire). Body mass index (BMI, weight/height ${ }^{2}$ ) was used to assess obesity (subjects were measured without shoes).

Of the I00 patients examined, $43 \%$ were smokers or had smoked within $4 \mathrm{~h}$ of the test (mean \% $\mathrm{HbCO}$ of total haemoglobin was 3.85 ( $\mathrm{SD} \mathrm{I} \cdot 50$, range $2 \cdot 1-7 \cdot 3$ ) and $57 \%$ were found to be non-smokers or had not smoked at least that morning (mean \% $\mathrm{HbCO}$ was I 30 (SD 0.26 , range $0.9-2.0$ )). On the basis of BMI, $58 \%$ of patients were overweight and $42 \%$ were normal weight with BMI between 20 and 25. Six patients were underweight for their height; of these four were smokers and two non-smokers. The weight category, smoking habit and \% $\mathrm{HbCO}$ of the patients are shown in the Table.

\begin{tabular}{|c|c|c|c|c|}
\hline \multirow[b]{2}{*}{ Patients } & \multicolumn{2}{|c|}{ Overweight } & \multicolumn{2}{|c|}{ Normal weight } \\
\hline & Smoker & Non-smoker & Smoker & Non-smoker \\
\hline No. & 25 & 33 & 17 & 25 \\
\hline$\%$ HbCO: Mean & $3 \cdot 74$ & $1 \cdot 30$ & $3 \cdot 97$ & I. 30 \\
\hline SD & $1 \cdot 5^{2}$ & 0.26 & $1 \cdot 30$ & 0.26 \\
\hline
\end{tabular}

The BMI showed that $58 \%$ of the arterial-disease patients examined were overweight, although between 47 and $54 \%$ of the general population of the UK above the age of $5^{\circ}$ years is believed to be overweight (Office of Population Censuses and Surveys, 1981). Obesity may be important in peripheral arterial disease, because of its association with increased levels of serum lipids (Gordon \& Kannel, 1973).

Garrow, J. S. (1981). In Recent Advances in Medicine no. 18, p. 77 [A. M. Dawson, N. Compston and J. M. Besser, editors]. Edinburgh and London: Churchill Livingstone.

Gordon, T. \& Kannel, W. B. (1973). Geriatrics 28, 80-88.

Greenhalgh, R. M., Laing, S. P., Cole, P. V. \& Taylor, W. (1981). British Yournal of Surgery 68, 605-607.

Office of Population Censuses and Surveys (r98r). OPCS Monitor 81/1. London: H.M. Stationery Office. 
Daily energy expenditure: evaluation of a factorial field technique against continuous calorimetry. By C. Geissler, T. Dzumbira and I. Noor, Department of Food and Nutritional Sciences, King's College (Kensington Campus), Campden Hill Road, London $W_{8}{ }_{7} A H$

The factorial field technique for measuring daily energy expenditure using an activity diary plus short-term indirect calorimetry (Durnin \& Brockway, 1959) was evaluated against continuous calorimetry in a room respirometer using eleven male and fourteen female subjects. Both methods were used to calculate $24 \mathrm{~h}$ energy expenditure and energy expenditure during the day and night-time sleep period and day-time wake period.

\begin{tabular}{|c|c|c|c|c|c|c|}
\hline \multirow{3}{*}{$n \ldots$} & \multicolumn{6}{|c|}{ Energy expenditure } \\
\hline & \multicolumn{2}{|c|}{$\begin{array}{l}24 \mathrm{~h} \\
(42)\end{array}$} & \multicolumn{2}{|c|}{$\begin{array}{c}\text { Sleep } \\
(39)\end{array}$} & \multicolumn{2}{|c|}{$\begin{array}{c}\text { Wake } \\
\text { (39) }\end{array}$} \\
\hline & Mean & SD & Mean & SD & Mean & sD \\
\hline \multicolumn{7}{|l|}{ Calorimetry (C): } \\
\hline $\mathrm{kJ}$ & 8170 & 2110 & 1780 & 398 & 6410 & 1940 \\
\hline kcal & $195^{2}$ & 504 & 425 & 95 & I 532 & $46_{4}$ \\
\hline \multicolumn{7}{|l|}{ Field method $(F)$ : } \\
\hline $\mathrm{kJ}$ & 8080 & I 720 & 2080 & 326 & 5970 & 1640 \\
\hline kcal & 1931 & 410 & 498 & 78 & 1426 & 392 \\
\hline $\mathrm{F}: \mathrm{C}$ & \multicolumn{2}{|c|}{0.99} & \multicolumn{2}{|c|}{$1 \cdot 17$} & \multicolumn{2}{|c|}{0.93} \\
\hline Range & \multicolumn{2}{|c|}{$(0.83-1 \cdot 25)$} & \multicolumn{2}{|c|}{$(0.96-1 \cdot 72)$} & $(0$. & 19) \\
\hline
\end{tabular}

Over the forty-two $24 \mathrm{~h}$ measurements the mean value by the field method was generally within $1 \%$ of that obtained by continuous calorimetry. However, individual daily energy expenditure can be under- or overestimated by -17 to $25 \%$. The cost of day-time activities was underestimated by a mean of $7 \%$, serendipitously compensated by an overestimation of the cost of sleep by both the Harris \& Benedict (1919) estimate of basal metabolic rate (BMR) and the recent prediction formulae of Schofield ( 1985$)$. On these bases, the mean cost of sleep was approximately $15 \%$ lower than the predicted BMR. However, correction of this error resulted in a mean underestimate of $5 \%$ for daily expenditure. The main sources of error in the field method are likely to be the accuracy of reproduction of the activity described in the diary card, the relation of the time of measurement to meal times, and transition time between one activity and another. The field method is therefore too inaccurate for the estimation of the daily expenditure of individuals but provides a close estimate of the energy expenditure of population groups.

Durnin, J. V. G. A. \& Brockway, J. M. (1959). British fournal of Nutrition 13, 41-53.

Harris, J. A. \& Benedict, F. G. (1919). A Biometric Study of Basal Metabolism in Man. Publication no. 279. Washington, DC: Carnegie Institution.

Schofield, W. N. (1985). Human Nutrition: Clinical Nutrition 39C, Suppl. I, 5-4I. 
Lower daily metabolic rates in post-obese than in lean subjects. By $\mathrm{C}$. Geissler, D. Miller and M. ShaH, Department of Food and Nutritional Sciences, King's College (Kensington Campus), Campden Hill Road, London $W 8{ }_{7} A H$

Interpretation of comparative studies of lean and obese subjects to determine the relative role of reduced thermogenesis, gluttony and sloth in the genesis of obesity, is hampered by the problem of expressing the results: per person, per $\mathrm{kg}$ body-weight, per kg lean body mass (LBM). To obviate this difficulty the daily metabolic rates of sixteen post-obese women and sixteen closely matched lean controls were measured in a room respirometer, at three levels of activity: sedentary, mild exercise (stepping for $\mathbf{2} \mathrm{h}$ total) to simulate normal activity, normal activity plus bicycle exercise for $4^{\circ} \mathrm{min}$ total at 'aerobic' level as popularly defined (60-80\% maximum oxygen consumption indicated by a pulse rate of 220 beats/min minus age in years, after $5 \mathrm{~min}$ of exercise). Mean anthropometric values of the post-obese and the lean subjects were respectively: age 32,32 years; weight 60.8,61.8 kg; height 1.646, I.660 m; Quetelet index (weight/height ${ }^{2}$ ) 22.5, 22.4; fat $28.5,26 \cdot 1 \%$; LBM $43.5,45 \cdot 6 \mathrm{~kg}$. Food was provided at the level of customary energy intake.

24 h energy expenditure

$\begin{array}{lrrrrrr}\text { Activity ... } & \overbrace{\text { Mean }}^{\text {Sedentary }} & \overbrace{\text { SD }}^{\text {Nean }} & & \text { SD } & & \overbrace{\text { Mean }}^{\text {Normal+aerobics }} \\ \begin{array}{c}\text { Post-obese (PO) } \\ \text { kJ }\end{array} & 5330 & 226 & 6700 & 289 & 7630 & 347 \\ \text { kcal } & 1273 & 54 & 1601 & 69 & 1823 & 83 \\ \begin{array}{c}\text { Lean (L) } \\ \text { kJ }\end{array} & 6440 & 289 & 7870 & 234 & 8920 & 272 \\ \text { kcal } & 153^{8} & 69 & 1882 & 56 & 2132 & 65 \\ \text { PO:L } & 0.83 & & 0.85 & & 0.86 & \end{array}$

The customary daily energy intake of the post-obese subjects maintaining their target weight $(5850 \mathrm{~kJ}$ ( $1398 \mathrm{kcal})$ ) was close to the experimental sedentary level of energy expenditure whereas the intake of the lean subjects $(8300 \mathrm{~kJ}$ ( $1945 \mathrm{kcal})$ ) was close to the energy expended during simulated normal activity, indicating that the free living post-obese women were less active than the lean. However, at each standardized level of activity the metabolic rate of the post-obese was lower than that of the lean by approximately $15 \%$. This could not be explained by differences in voluntary nor obligatory activity, nor by the consumption of the stimulants nicotine or caffeine. More than $90 \%$ of the difference occurred during the day, indicating that reduced thermogenesis was more important than differences in basal metabolic rate. The results indicate that human obesity is at least partly a metabolic defect and suggest that thermogenic stimulants could have an important role in its control.

Energy expenditure during sleep was no higher after daytime normal plus 'aerobic' activity (NA) than after normal activity (N) in either the post-obese (NA $3.18, \mathrm{~N} 3.18 \mathrm{~kJ} / \mathrm{min}$ ) or the lean (NA $3.47, \mathrm{~N}_{3} .56 \mathrm{~kJ} / \mathrm{min}$ ) subjects. This shows that there was no prolonged increase in metabolic rate after 'aerobic' exercise of this level and duration. 
A comparison of the thermic responses to two $2 \mathrm{MJ}$ meals provided as a liquid formula or as solid food. By S. M. RoBinson and D. A. York, Department of Nutrition, School of Biochemical and Physiological Sciences, University of Southampton, Southampton $\mathrm{SO}_{9} \mathrm{TU}$

The increase in energy expenditure following feeding (TEF) appears to exceed the predicted 'costs' of the processing of the ingested nutrients and has been shown to vary between individuals, with meal size and with meal composition (Owen et al. 1986). Golay et al. (1986) reported a reduced thermic response to glucose infusion when compared with glucose ingestion, and attributed this discrepancy to the 'costs' associated with the cephalic responses to feeding. We have investigated the possibility that TEF might differ with a variation in the form of the food, since there might be an additional anticipatory response to the sight and smell of appetizing food. The responses to feeding two meals of similar composition and size but provided in the form of familiar food or as a liquid meal (Ensure ${ }^{\circledR}$ ) have been compared.

Resting metabolic rate (RMR) and the $4 \mathrm{~h}$ thermic responses to a $2 \mathrm{MJ}$ meal (Ensure or 'solid food' ( 35 g cornflakes, $130 \mathrm{~g}$ semi-skimmed milk, $12 \mathrm{~g}$ sugar, 220 $g$ orange juice and $40 \mathrm{~g}$ cheddar cheese)) were measured in eight female subjects (mean body mass index 22. I (SE 0.8 ), age 19-21 years).

The mean RMR values were very similar on both occasions (3.69 (SE 0.16$)$ and 3. $7 \mathrm{I}(\mathrm{SE} 0 . \mathrm{I} 6) \mathrm{kJ} / \mathrm{min}$ ) but the total $(4 \mathrm{~h})$ thermic response to the 'solid food' meal tended to be greater than that to the Ensure meal (I52 (SE 6) and I35 (SE II) kJ respectively, not significant). Analysis by two-way ANOVA of the mean time courses of the two responses showed that there was a significant interaction between the two meals and time, and the increase in energy expenditure was significantly greater following the 'solid food' meal at 20,30 and $40 \mathrm{~min}$ post-prandially $(P<0.05)$.

It would appear that the form of the meal does influence its thermic effect and that this is due to differences in the cephalic responses to feeding. These may include the anticipatory responses to feeding (possibly mediated by the sympathetic nervous system) as well as to differences in the costs of chewing and swallowing solid food when compared with a liquid meal.

Golay, A., Schutz, Y., Felber, J.-P., De Fronzo, R. A. \& Jequier, E. (1986). International Fournal of Obesity 10, 107-1 16.

Owen, O. E., Kavle, E., Owen, R. S., Polansky, M., Caprio, S., Mozzoli, M. A., Kendrick, Z. V., Bushman, M. C. \& Boden, G. (1986). American fournal of Clinical Nutrition $44,1-19$. 
Very low birth weight infants given total parenteral nutrition: longitudinal balance studies of nitrogen and energy. By JOCELYN R. SAINI and JANE B. MoRgan, Department of Biochemistry, University of Surrey, Guildford, Surrey GU2 ${ }_{5} \mathrm{XH}$ and I. Z. KovaR, Department of Child Health, Charing Cross Hospital, London W6 $8 R F$

Full oral feeding in the very low birth weight infant $\left(<_{1200 \mathrm{~g}, \text { VLBW }}\right)$ is often not achievable for days or weeks, and total parenteral nutrition (TPN) is the only source of nutrition. The aim of the present study was to validate the adequacy of TPN in VLBW by comparing nitrogen retention and energy (E) intake with intrauterine accretion values, and to assess growth performance.

Eight VLBW (four male, four female), mean birth weight $94^{\circ} \mathrm{g}$ (range 760-1 100 g) and median gestation 27 weeks (range $25^{-29}$ weeks), had serial $72 \mathrm{~h}$ balances of $\mathrm{N}$ and $\mathrm{E}$ at 5,15 and $25 \mathrm{~d}$ postnatal age (PNA) (balance periods $\mathrm{I}, 2$ and 3 respectively). All infants were ill and initially ventilator-dependent. TPN was given from 3 d PNA with $\operatorname{Vamin}^{\circledR}$ (KabiVitrum, Sweden) as the only $\mathrm{N}$ source. $\mathrm{N}$ analysis was by a microKjeldahl technique and $\mathrm{E}$ by bomb calorimetry. Infants were weighed daily and had crown-heel length and head circumference measured weekly.

\section{$N$ and $E$ balances in $V L B W$}

\begin{tabular}{|c|c|c|c|c|c|c|}
\hline \multirow[t]{2}{*}{ Balance period ... } & \multicolumn{2}{|c|}{ I $(n 8)$} & \multicolumn{2}{|c|}{$2(n 8)$} & \multicolumn{2}{|c|}{$3(n 6)$} \\
\hline & Mean & SEM & Mean & SEM & Mean & SEM \\
\hline Postconceptional age & & & & & & \\
\hline$(\mathrm{PCA})(\mathrm{d})$ & 196 & 4 & 206 & 3 & 217 & 4 \\
\hline $\begin{array}{l}\text { Body-weight (g) } \\
\text { Incremental body- }\end{array}$ & 800 & 44 & 925 & 35 & 1020 & 53 \\
\hline $\begin{array}{l}\text { weight }(\mathrm{g} / \mathrm{kg} \text { per d) } \\
\mathrm{E} \text { intake }\end{array}$ & rof & 2 & 10 & 2 & 12 & 4 \\
\hline $\begin{array}{l}(\mathrm{kJ} / \text { kg per d) } \\
(\mathrm{kcal} / \mathrm{kg} \text { per } \mathrm{d})\end{array}$ & $\begin{array}{r}276 \\
66\end{array}$ & $\begin{array}{l}4 \cdot 2 \\
I\end{array}$ & $\begin{array}{r}372 \\
89\end{array}$ & $\begin{array}{c}25 \cdot 1 \\
6\end{array}$ & $\begin{array}{r}335 \\
80\end{array}$ & $\begin{array}{c}37 \cdot 7 \\
9\end{array}$ \\
\hline $\begin{array}{l}\mathrm{N} \text { retention } \\
(\mathrm{mg} / \mathrm{kg} \text { per } \mathrm{d}) \\
\mathrm{N} \text { retention }\end{array}$ & I 55 & 36 & $340^{\circ}$ & 34 & $323^{\circ}$ & 46 \\
\hline $\begin{array}{l}\mathrm{N} \text { retention } \\
\quad \text { (\% intake) }\end{array}$ & $4^{8}$ & 8 & $69^{*}$ & 5 & $67^{*}$ & 8 \\
\hline
\end{tabular}

Significantly different from balance period I (Student's $t$ test): $\bullet P<0.01$.

$\ddagger$ Excludes one VLBW with oedema.

$\mathrm{N}$ retention ( $\mathrm{mg} / \mathrm{kg}$ per d) was significantly lower than the accepted intrauterine accretion rates at $3 \mathrm{~d}$ PNA but subsequently was similar. $\mathrm{N}$ retention $(\mathrm{mg} / \mathrm{kg}$ per $\mathrm{d}$ ) was similar to that found in formula-fed infants of comparable PCA and PNA. TPN in VLBW permits approximation of intrauterine $N$ accretion after $200 \mathrm{~d}$ PNA and in ill infants matches that seen in healthy, enterally fed infants.

JRS is an MRC/AFRC Training Fellow in Human Nutrition. 
Metabolic adaptation to a marginal energy intake. By N. KENNEDY, V. BADALOO and A. JACKSON*, Tropical Metabolism Research Unit, University of the West Indies, Kingston 7, famaica

We have shown previously that young children were able to maintain body-weight on a gross energy intake of $352 \mathrm{~kJ}(84 \mathrm{kcal}) / \mathrm{kg}$ per d (Jackson et al. 1983). This work has been extended to observe the response to $318 \mathrm{~kJ}(76 \mathrm{kcal}) / \mathrm{kg}$ per d.

Six male Jamaican children, aged 8-28 months, were studied for three consecutive periods of $\mathrm{I}$ week each. The children had recently recovered from malnutrition, were not wasted and were free of infection. Diets provided a gross energy intake during the 1 st, 2nd and 3 rd weeks of $45^{2}, 318$ and $364 \mathrm{~kJ}$ ( 108,76 and $87 \mathrm{kcal}) / \mathrm{kg}$ per $\mathrm{d}$ respectively, $\mathrm{I} \cdot 7 \mathrm{~g}$ protein $/ \mathrm{kg}$ per $\mathrm{d}$, and supplements of vitamins and trace elements. All of the food offered was consumed. Each child was weighed at the same time each morning on an electronic balance.

Using linear regression analysis, all the children gained weight on $45^{2} \mathrm{~kJ}$ ( 108 $\mathrm{kcal}) / \mathrm{kg}$ per d (2.3 (SD I.3) $\mathrm{g} / \mathrm{kg}$ per d) and five of six children gained weight on $364 \mathrm{~kJ}(87 \mathrm{kcal}) / \mathrm{kg}$ per d $(2.7$ (SD 2.3) $\mathrm{g} / \mathrm{kg}$ per d; not significantly different (Student's $t$ test)). On $318 \mathrm{~kJ}(76 \mathrm{kcal}) / \mathrm{kg}$ per d all the children lost weight $(-5.4$ (SD I.3) $\mathrm{g} / \mathrm{kg}$ per d); significantly different from each of the other dietary periods $(P<0.0005)$. The rate of loss was significantly greater during the first part $(-9.6$ (SD $7 \cdot 1$ ) $\mathrm{g} / \mathrm{kg}$ per d) than at the end of the 2 nd week $(-2.7($ SD 4.5$) \mathrm{g} / \mathrm{kg}$ per d; $P<0.05$ ), with most children showing a break point after $3-4 \mathrm{~d}$ followed by a tendency towards a steady weight by day 7 .

Surprisingly, weight gain on $364 \mathrm{~kJ} \mathrm{(87} \mathrm{kcal)/kg} \mathrm{per} \mathrm{d,} \mathrm{following} \mathrm{a} \mathrm{period} \mathrm{on} 318$ $\mathrm{kJ}(76 \mathrm{kcal}) / \mathrm{kg}$ per $\mathrm{d}$, was the same as that on $452 \mathrm{~kJ}(108 \mathrm{kcal}) / \mathrm{kg}$ per d. In the previous study no weight gain was seen when $364 \mathrm{~kJ}(87 \mathrm{kcal}) / \mathrm{kg}$ per d followed a period on $45^{2}$ or $410 \mathrm{~kJ}$ (108 or $98 \mathrm{kcal}$ )/kg per d (Jackson et al. 1983). As no formal measurements of energy expenditure were made, we can only speculate as to the possible mechanisms whereby body-weight was defended so effectively. The relatively large differences in energy balance cannot be explained by single changes in activity, the quality of tissue deposited, or changes in body composition. Assuming balanced tissue deposition, $21 \mathrm{~kJ}(5 \mathrm{kcal}) / \mathrm{g}$, the energy available for basal requirements would be 272 and $377 \mathrm{~kJ}(65$ and $90 \mathrm{kcal}) / \mathrm{kg}$ per $\mathrm{d}$ on 364 and $452 \mathrm{~kJ}$ ( 87 and $108 \mathrm{kcal}) / \mathrm{kg}$ per d respectively, which compares with a 'total energy utilization' of $280 \mathrm{~kJ}(66 \mathrm{kcal}) / \mathrm{kg}$ per d in malnutrition and $33 \mathrm{I} \mathrm{kJ}(79 \mathrm{kcal}) / \mathrm{kg}$ per $\mathrm{d}$ after recovery (Kerr et al. 1978).

These observations suggest that on $318 \mathrm{~kJ}(76 \mathrm{kcal}) / \mathrm{kg}$ per $\mathrm{d}$ an adaptive mechanism, which allowed for a saving of about $105 \mathrm{~kJ} \mathrm{(25} \mathrm{kcal)/kg} \mathrm{per} \mathrm{d,} \mathrm{was}$ being brought into play over $3-4 \mathrm{~d}$, and persisted into the period on $364 \mathrm{~kJ}(87$ $\mathrm{kcal}) / \mathrm{kg}$ per d.

The authors thank the Wellcome Trust for support.

Jackson, A. A., Golden, M. H. N., Byfield, R., Jahoor, F., Royes, J. \& Soutter, L. (1983). Human Nutrition: Clinical Nutrition 37C, 433-446.

Kerr, D. S., Stevens, M. C. G. \& Robinson, H. M. (1978). Metabolism 27, 4 I 1-435.

-Present address: Department of Nutrition, Southampton University, Medical and Biological Sciences Building, Bassett Crescent East, Southampton $\mathrm{SO}_{9} \mathrm{TU}$. 
Detection of secretory IgA antibodies to common food protein in stimulated human parotid saliva. By CaITRIONA BRADY and MiCHAEL J. GiBney, Division of Nutritional Sciences, Department of Clinical Medicine, Trinity College Medical School, St fames' Hospital, Dublin 8, Irish Republic

Antibodies (IgG) to common food proteins are routinely detected in human serum with elevations recorded for specific antibodies in certain diseases. Access to secretory antibodies $(\operatorname{IgA})$ to food proteins has generally been limited to those present in breast-milk or through mucosal biopsy of the intestine. The purpose of the present study was to evaluate the possibility of using saliva as an accessible source of secretory (s) IgA antibodies to common food proteins.

Salivary flow was stimulated in healthy volunteers with drops of lemon juice on the tongue. Parotid saliva was collected using a Curby cup and stored at $-20^{\circ}$. An enzyme immunoassay (EIA) was developed to detect IgA antibodies to Streptococcus mutans, ovalbumin, casein and $\beta$-lactoglobulin. S. mutans was selected as a positive control given that salivary sIgA antibodies to $S$. mutans, a major oral bacteria, have been widely reported. Several alterations to the basic EIA were implemented. The level of Tween 20 in the washing buffer was increased from 0.5 to $5 \mathrm{~g} / 1$ and both fetal calf serum and bovine serum albumin were added to the buffer case each at a concentration of $0.1 \mathrm{~g} / \mathrm{l}$. Two successive peroxidase conjugated anti-sera were used in successive incubations: goat (IgG)-anti-human sIgA and rabbit (IgG)-anti-goat IgG. Serum IgG antibodies to the test proteins were measured using a single conjugate, conventional EIA. The results are shown in the Table (optical density $490 \mathrm{~nm}, n$ ).

\begin{tabular}{|c|c|c|c|c|c|c|c|c|}
\hline & \multicolumn{2}{|c|}{ S. mutans } & \multicolumn{2}{|c|}{ Ovalbumin } & \multicolumn{2}{|c|}{ Casein } & \multicolumn{2}{|c|}{$\beta$-lactoglobulin } \\
\hline & Mean & SD & Mean & SD & Mean & SD & Mean & SD \\
\hline $\begin{array}{l}\text { Serum IgG* } \\
\text { Serum } \operatorname{Ig} A+\end{array}$ & $1 \cdot 03$ & 0.01 & 0.75 & 0.38 & $0.5 I$ & $0 \cdot 21$ & 0.48 & 0.16 \\
\hline Serum sIgA $\dagger$ & 0.98 & $0.2 \mathrm{I}$ & $0 \cdot 39$ & 0.15 & 0.46 & & & 0.10 \\
\hline
\end{tabular}

The specificity of the sIgA EIA was verified by inhibition studies. The recorded levels of antibodies in saliva were not related to either total salivary protein or total salivary IgA. Of the microtitre plates examined the most favourable signal:noise ratio was found with Removastrip (Dynatech). These results show that stimulated human parotid saliva is a readily accessible fluid for the measurement of secretory antibodies to common food protein.

The present study was funded by the Nestle Nutrition Research Grants Programme. 
Effect of increasing levels of dietary eicosapentaenoic (20:5n-3) and docosahexaenoic (22:6n-3) acids on lymphocyte phospholipid composition and cell-mediated immunity in the mouse. By ALISON Hinds and T. A. B. SANDERS, King's College (Kensington Campus), Campden Hill Road, London $W_{8}{ }_{7} A H$

Diets in which all of the fat is provided by fish oil have been shown to be immunosuppressive in mice (Prickett et al. 198I) These effects have been attributed to the influence of eicosapentaenoic $(20: 5 n-3)$ and docosahexaenoic $(22: 6 n-3)$ acids on prostaglandin and leukotriene production. The mode of administration of fish oil effects the cell-mediated immune (CMI) response (Sanders et al. 1985). When administered acutely by mouth, CMI response was suppressed, but the same dose incorporated into the diet had no effect. We report the influence of higher doses of a fish oil (MaxEPA; Seven Seas Health Care, Hull) on CMI response using the mouse popliteal lymph node assay technique of Mertin \& Stackpoole (198I).

To study the chronic effects, CBA pure-strain mice ( $15 \mathrm{~g}$, eight animals per group) were fed on semi-synthetic diets containing $200 \mathrm{~g} \mathrm{fat} / \mathrm{kg}$. The proportion of saturated fats and linoleic acid in each diet was kept constant. The experimental diets contained increasing proportions of eicosapentaenoic and docosahexaenoic acids in place of oleic acid in the control diet. The animals were fed for 4 weeks and the Host $v$. Graft reaction was studied using the popliteal lymph node assay technique. A-strain mice were used as a source of allogeneic cells. An increase in popliteal lymph node weight $4 \mathrm{~d}$ after inoculation was taken as an indication of CMI response. Spleens were collected from the animals, lymphocyte suspensions prepared from them, and the fatty acid composition of the phospholipid fraction determined by capillary gas-liquid chromatography (see Table).

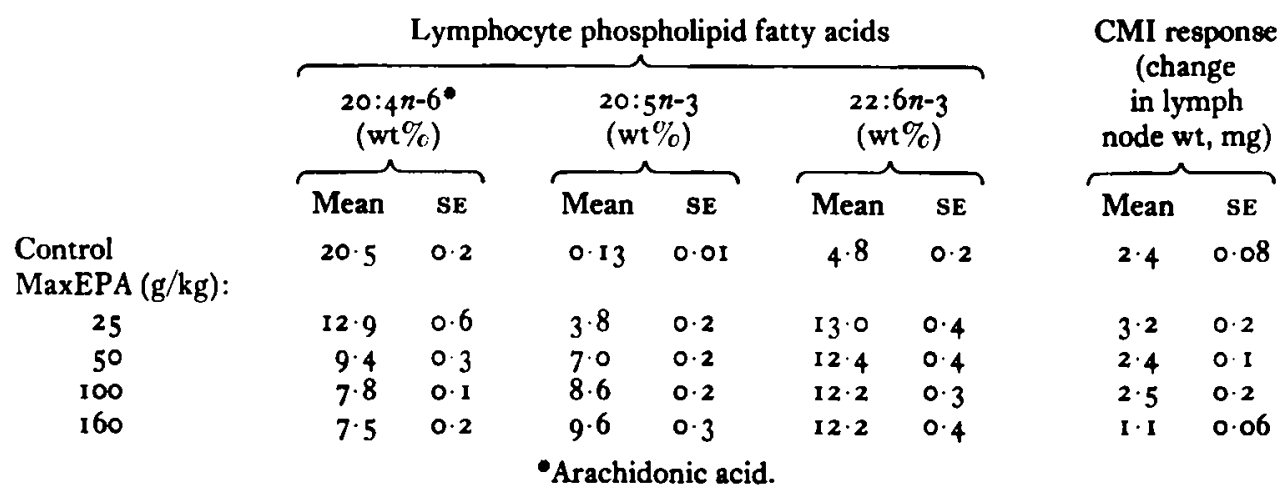

Only the highest intakes of eicosapentaenoic and docosahexaenoic acids decreased the CMI response, but major changes in lymphocyte phospholipid fatty acid composition were apparent at lower doses.

Mertin, J. \& Stackpoole, A. (198I). Nature 294, 456-458.

Prickett, J. D., Robinson, D. R. \& Steinberg, A. D. (1981). Fournal of Clinical Investigation 68, 556-559.

Sanders, T. A. B., Grahame, M. \& Mistry, M. (1985). Proceedings of the Nutrition Society $44,6 A$. 
Serum glucose and insulin response to various levels of glucose, maltose and two maltodextrins in men and women. By Celia A. Williams, Department of Biochemistry, University of Surrey, Guildford, Surrey $G_{2}{ }_{5} X H$, and I. Macdonald, Department of Physiology, United Medical and Dental Schools, Guy's Hospital Campus, London SE $19 R T$

The size of a glucose polymer might be expected to influence gastric emptying, the rate of its hydrolysis and, hence, the rate of absorption of its glucose components. The ensuing serum glucose and insulin response could therefore be affected.

After an overnight fast, twelve male and ten female healthy, non-obese volunteers were given test meals comprising glucose, maltose, maltodextrin $\mathrm{DE} 5$ or maltodextrin DE 20 at concentrations of $0.25,0.5$ and $\mathrm{I} \cdot 0 \mathrm{~g} / \mathrm{kg}$ body-weight. Blood samples were collected before and at 10, 20, 30,60 and $90 \mathrm{~min}$ after ingestion of the meal. Serum was assayed for glucose and insulin. The areas under the serum glucose and insulin response curves were calculated for each individual and used in the calculation of mean response and regression analysis of response against dose level.

Regression analysis $(\mathrm{y}=\mathrm{a}+\mathrm{bx})$ of serum response on dose of carbohydrate

\begin{tabular}{|c|c|c|c|c|c|c|}
\hline & $n$ & $a$ & $b$ & $\mathrm{SE} b$ & $r$ & $P<$ \\
\hline \multicolumn{7}{|c|}{ Serum glucose: } \\
\hline Male & 80 & 4.99 & $26 \cdot 64$ & $6 \cdot 5^{6}$ & 0.42 & 0.001 \\
\hline Female & 75 & $7 \cdot 60$ & $5 \cdot 77$ & $4 \cdot 2 I$ & 0.16 & not significant \\
\hline Serum insulin & & & & & & \\
\hline Male & 80 & $26 \cdot 16$ & $885 \cdot 5^{8}$ & 104.47 & 0.69 & 0.001 \\
\hline Female & 75 & $26 \cdot 5^{8}$ & $5^{62.75}$ & $48 \cdot 17$ & $0.8 \mathrm{I}$ & 0.001 \\
\hline
\end{tabular}

The serum glucose and insulin responses to the five different carbohydrates were not significantly different at comparable dose levels. The female serum glucose response was not influenced by the level of carbohydrate given, the slope of the response against dose level not being significant. However, the male serum glucose response increased with the level of carbohydrate given, the slope of the line being significantly different from zero $(P<0.01)$. The serum insulin response was dose dependent in males and females, both regression analyses of serum insulin response against carbohydrate dose produced lines with highly significant slopes $(P<0.001)$. The serum insulin response of the females to body-weight-related loads of carbohydrate was consistently lower than that of the males by approximately $40 \%$.

Possible explanations for the sex difference in response to the meals include differences in gastric emptying, the rate of glucose absorption or metabolism of glucose from the given test meals. These results support the suggestion that the serum insulin response to a glucose meal is more directly related to the quantity of glucose ingested than is the serum glucose response. 
Acute effect of exercise on ascorbate content of plasma and lymphocytes.

By M. Gleeson and R. J. Maughan, Department of Environmental and

Occupational Medicine, University Medical School, Aberdeen $A B{ }_{2} 2 Z D$

Physiological stress such as myocardial infarction is associated with a rapid and profound reduction in plasma and leucocyte ('buffy coat') ascorbic acid (AA) content, approaching the deficiency level (Hume et al. 1972). Other forms of stress including emotional stress, trauma, surgery and acute infection also appear to reduce blood levels of AA (Schorah, 198I). Our interest was to examine the effect of prolonged strenuous physical exercise on plasma and lymphocyte AA levels in man, since a $2 \mathrm{~h}$ football training session involving vigorous exercise has also been reported to decrease leucocyte AA content (Boddy et al. 1974).

A venous blood sample was obtained from eight male subjects before and within 5 min after a marathon race $(42.2 \mathrm{~km})$ held in Aberdeen in May 1986. The AA content of plasma and isolated lymphocytes was determined by high performance liquid chromatography. Plasma volume changes were calculated from haemoglobin and packed cell volume measurements as described by Dill \& Costill (1974).

The mean (with SE) finishing time of these runners was $235.2(35.6) \mathrm{min}$. There was a non-significant decrease in plasma volume of $1 \cdot 7(2.5) \%$ at the end of the race. Plasma AA concentration significantly increased from $54.7(9.4) \mu \mathrm{mol} / 1$ before the race to $79.0(12.3) \mu \mathrm{mol} / 1$ after the race $(P<0.001)$. Lymphocyte AA content also increased from $17 \cdot 4(1 \cdot 4)$ to $21 \cdot 3(2 \cdot 6) \mu \mathrm{mol} / \mathrm{g}$ lymphocyte protein following the race $(P<0.05)$.

Although these results contrast with the effects of other forms of stress on blood AA levels in man (see Schorah, 1981), they appear similar to findings of a markedly elevated plasma AA concentration in rats during hypoxia (Arad et al. 1985), following haemorrhage, and after administration of adrenocorticotrophic hormone (Sayers et al. 1945). The highest concentration of AA in the mammalian body is in the adrenal gland and there is an inverse relation between the amount of AA in the gland and the increased activity of the gland in states of stress (Sayers et al. 1945). The adrenal gland may be the major source of AA efflux into the circulation during exercise stress and this is probably mediated through adrenocorticotrophic hormone.

The present study was supported by the Health Promotion Research Trust.

Arad, I., Sidi, A. \& Shohami, E. (1985). Journal of Neurochemistry 45, 766-769.

Boddy, K., Hume, R., King, P. C., Weyers, E. \& Rowan, T. (1974). Clinical Science and Molecular Medicine 46, 449-456.

Dill, D. B. \& Costill, D. L. (1974). Foumal of Applied Physiology 37, 247-248.

Hume, R., Weyers, E., Rowan, T., Reid, D. S. \& Hillis, W. S. (1972). British Heart Jourmal 34, 238-243.

Sayers, G., Sayers, M. A., Liang, T. Y. \& Long, C. N. H. (1945). Endocrinology 37, 96-I 10.

Schorah, C. J. (I98I). In Vitamin C (Ascorbic Acid), pp. 23-47 [J. N. Counsell and D. H. Hornig, editors]. London: Applied Science. 
Thermic responses to spontaneous meals in the rat. By NANCY J. Rothwell, Michael J. Stock and Alison E. Tedstone. Department of Physiology, St George's Hospital Medical School, Tooting, London $S W_{1} 7$ ORE

Ingestion of a meal has long been known to stimulate metabolic rate. In order to investigate the relative importance of pregastric (anticipation, oro-nasal sensations, etc.) and gastric stimuli in the thermogenic response to a meal, resting oxygen consumption $\left(\mathrm{VO}_{2}\right)$ was measured following spontaneous and force-fed (gastric intubation) meals. Male rats ( $n$ 16) were trained over a 2-week period to expect and consume a meal (fresh liver) at the same time (ro.00 hours) each day.

Mean $\mathrm{VO}_{2}$ at 08.00 hours was $\mathrm{I}_{3} .23$ (SE 0.53$) \mathrm{ml} / \mathrm{kg}$ body-weight ${ }^{0.75}$ per min. $\mathrm{VO}_{2}$ tended to increase during the $2-\mathrm{h}$ period preceding the expected meal, but all meals caused a further significant increase in $\mathrm{VO}_{2} .40 \mathrm{~kJ}$ of liver produced the largest increase in $\mathrm{VO}_{2}(33.2$ (SE 3.4$) \%$ ), whereas a less palatable but isoenergetic meal (2.5 g Complan ${ }^{\circledR}$, Boots, Nottingham) produced a smaller rise (25. I (SE 3.3 ) $\%$ ). Surprisingly, a zero-energy meal ( $2.5 \mathrm{~g}$ celery, $<\mathrm{I} \cdot 0 \mathrm{~kJ}$ ) caused a I $7 \cdot \mathrm{I}$ (SE 3.7$)$ $\%$ increase in $\mathrm{VO}_{2}$. In contrast to these voluntary meals, tube-feeding $40 \mathrm{~kJ}$ Complan produced only a 12.2 (SE 2.0 ) \% increase in $\mathrm{VO}_{2}$. When no meal was presented, the rise in $\dot{V O}_{2}$ over the same 'postprandial' period was very much smaller ( 7.2 (SE I .8) \%) but still significant $(P<0.05)$. The sympathetic $\beta$-receptor antagonist propranolol (20 mg/kg subcutaneously, at 08.00 and 10.00 hours) completely inhibited the rise in $\dot{V} \mathrm{O}_{2}$ after spontaneous meals of liver or Complan. However, propranolol did not affect the prefeeding increase in $\dot{V} \mathrm{O}_{2}$, which suggests that this may have been due to greater physical activity in anticipation of food.

In similarly trained, conscious, unrestrained rats, recordings from an inplanted radiotelemetry thermistor probe in the intrascapular brown adipose tissue showed increases in temperature preceding and following spontaneously consumed meals (peak rise of I $6\left(\mathrm{SE} 0.2, n_{4}\right)^{\circ}$, I h post-feeding). Once again, propranolol did not affect the prefeeding increase but significantly reduced the postprandial response.

The results suggest that in addition to any effects of absorbed nutrients, the acute thermic effect of a meal also depends on anticipatory, oro-nasal and gastrointestinal stimuli. Thus, the size of the response can depend not only on the energy and nutrient content of the meal, but also on taste, smell, bulk and the previous meal-feeding experience of the animal. Inhibition of thermic responses by a $\beta$-adrenergic antagonist indicates that a major part of the response depends on sympathetically mediated thermogenesis and this appears to involve increases in brown fat thermogenesis. 
Effect of the level and type of fat intake on energy balance and thermogenesis in the rat. By NANCY J. Rothwell and MichaEL J. Sтоск, Department of Physiology, St George's Hospital Medical School, Tooting, London $S W_{1} 7$ oRE

Both the level and type of ingested fat can affect energy balance and thermogenesis, and we have observed marked reductions in energetic efficiency and increased brown adipose tissue (BAT) activity in animals tube-fed medium-chain triglyceride (MCT) (Gurr et al. 1979). We have now compared the effects of feeding groups $(n)$ of young, Sprague-Dawley rats on high-fat (50\% metabolizable energy, $\mathrm{ME}$ ) diets containing either long-chain saturated (lard), unsaturated (maize oil), mixed (lard/maize oil) or medium-chain (eight-carbon and ten-carbon) fats with those fed on a low ( $7 \% \mathrm{ME})$, mixed fat (lard/maize oil) diet (control).

There were no gross changes in energy balance, except that ME intake $(\mathrm{kJ} / \mathrm{kg}$ body-weight ${ }^{0.75}$ per d) over the $15 \mathrm{~d}$ experiment was significantly increased $(8-9 \%)$ in rats fed on the mixed or saturated high-fat diets, compared with controls. However, body-weight and energy gains were increased only in those fed on the saturated-fat diet, and energy expenditure (corrected for body size) was comparable for all groups.

Resting oxygen consumption $\left(\mathrm{VO}_{2}, \mathrm{ml} / \mathrm{min}\right.$ per $\mathrm{kg}$ body-weight ${ }^{0.75}$ ) measured after $7 \mathrm{~d}$ was increased significantly $(P<0.05)$ in rats fed on the high-fat mixed ( 17.0 (SE 0.4)), unsaturated (17.4 (SE 0.4)) or MCT (I 8.4 (SE 0.3)) diets compared with controls ( 15.8 (SE O. I)), but unaffected in those given only saturated fat ( 16.4 $(\mathrm{SE} \quad 0.3)$ ). Injection of the $\beta$-adrenergic antagonist propranolol $(20 \mathrm{mg} / \mathrm{kg}$ subcutaneously) caused slight reductions in $\mathrm{VO}_{2}$ of controls (0.7 (SE 0.3$)$ ) and rats fed on the saturated high-fat diet (I.2 (SE 0.3$))$, but produced much larger $(P<0 . \mathrm{OI})$ reductions in animals consuming the mixed $(2.2$ (SE 0.3$)$ ), unsaturated (2.7 (SE 0.3$))$ or MCT (2.8 (SE 0.3$))$ diets. Thermogenic activity of interscapular BAT, assessed from the specific binding of guanosine diphosphate (GDP) to isolated mitochondria, was increased in all high-fat groups (saturated 74 (SE 7), unsaturated 85 (SE 6), mixed 96 (SE 7), MCT 107 (SE 7) $\mathrm{pmol} / \mathrm{mg}$ protein) compared with controls $(59$ (SE 4$), P<0.05$ ). BAT GDP-binding correlated with $\mathrm{VO}_{2}(r 0.94)$ and with the reduction in $\mathrm{VO}_{2}$ by propranolol $(r 0.92)$.

These results indicate that all the high-fat diets stimulated thermogenesis in BAT to some extent, with MCT and unsaturated fat diets producing slightly greater effects than the long-chain saturated high-fat diet, even in the absence of hyperphagia. The high-fat diets apparently increased sympathetic outflow, since $\beta$-adrenergic blockade caused significant reductions in metabolic rate. However, the effects on energy balance were small, probably because increases in sympathetically mediated thermogenesis were partially offset by simultaneous reductions in the energy costs of lipid deposition.

Gurr, M. I., Rothwell, N. J. \& Stock, M. J. (1979). Proceedings of the Nutrition Society 38, $6 \mathrm{~A}$. 
Thermogenic sensitivity to adrenergic agonists of brown adipocytes from

'cafeteria'-fed rats. By NanCy J. Rothwell, Michael J. Stock and

DeEPAK K. Sudera, Department of Physiology, St George's Hospital

Medical School, Tooting, London $S W_{\mathrm{I}} 7$ oRE

'Cafeteria'-fed rats exhibiting diet-induced thermogenesis show increases in thermogenic capacity and activity of brown adipose tissue (BAT) which are due to elevated sympathetic drive. However, sensitivity to adrenergic agonists have not been studied systematically, nor correlated with in vitro BAT responses, and these might be expected to decrease following chronic sympathetic stimulation. In the present study, thermogenic sensitivity to incremental doses of noradrenaline (NA) in control and cafeteria-fed rats (sixteen per group) was assessed (08.00-16.00 hours) from measurements of resting oxygen consumption $\left(\mathrm{VO}_{2}\right) 2 \mathrm{~h}$ before and $2 \mathrm{~h}$ after NA injection. Brown adipocyte respiratory sensitivity to NA, isoprenaline, prenalterol and clenbuterol was also measured in vitro with an oxygen electrode.

Basal and maximal NA-induced in vivo $\mathrm{VO}_{2}\left(\mathrm{ml} / \mathrm{min}\right.$ per $\mathrm{kg}$ body-weight $\left.{ }^{0.75}\right)$ of control rats ( 14.9 (SE O.3) and 25 (SE I . 6) respectively) were significantly $(P<0.01)$ lower than those of cafeteria-fed rats ( 17.4 (SE 0.3 ) and 35 (SE I .6) respectively). Although the maximal response in both groups was achieved with a similar dose of $\mathrm{NA}(0.4 \mathrm{mg} / \mathrm{kg}$ body-weight), cafeteria-fed rats exhibited increased sensitivity to submaximal doses of $\mathrm{NA}\left(\mathrm{EC}_{50}\right.$ (effective concentration which produces $50 \%$ of maximal response): control $0 \cdot 2$, cafeteria $0.1 \mathrm{mg} / \mathrm{kg}$ ).

Basal respiration of brown adipocytes from cafeteria-fed rats (135 (SE II) nmol $\mathrm{O}_{2} /$ min per $10^{-6}$ cells) was higher than that for cells from control rats (79 (SE 4) $P<0.001$ ) and was not inhibited by the $\beta$-adrenergic antagonist propranolol (10 $\mu \mathrm{M})$. The rank order of potency for adrenergic stimulation of BAT cell respiration was isoprenaline $>\mathrm{NA}>$ prenalterol $=$ clenbuterol for control rats, and isoprenaline $>$ NA $>$ prenalterol $>$ clenbuterol for cafeteria-fed rats. Maximal respiration induced by all agonists tended to be higher in brown adipocytes from cafeteria-fed rats (significant, $P<0.05$, for isoprenaline and clenbuterol). Dose-response curves for isoprenaline, prenalterol and NA in BAT cells from cafeteria-fed rats were displaced to the left (two- to fourfold decrease in $\mathbf{E C}_{50}$ ), suggesting an increased sensitivity, particularly to $\beta_{1}$-adrenoreceptor activation.

The total number of BAT $\beta$-adrenoreceptors is increased in cafeteria-fed rats, but the ratio of $\beta_{1}: \beta_{2}$ adrenoreceptors is decreased (Rothwell et al. 1986). This suggests that the greater thermogenic sensitivity to adrenergic agonists in cafeteria-fed rats could be due to increased coupling of BAT $\beta_{1}$-adrenoreceptors to post-receptor activation of adenyl cyclase. The increase in thermogenic capacity observed in cafeteria-fed rats in vivo is probably due to an increase in mass of active BAT.

Rothwell, N. J., Stock, M. J. \& Sudera, D. K. (I986). European Yournal of Pharmacology 125, 313-323. 
Influence of protein deficiency on the metabolic response to endotoxin in young rats. By M. M. JEPSON and D. J. Millward, Nutrition Research Unit, London School of Hygiene and Tropical Medicine, 4 St Pancras Way, London NWI $2 P E$

Well-fed young rats respond to endotoxin with fever, anorexia, increased rates of whole body oxygen consumption $\left(\mathrm{VO}_{2}\right)$ and liver protein synthesis, and suppressed muscle protein growth as a result of both decreased synthesis and increased degradation of muscle protein (Jepson et al. $1986 a, b$ ). The present paper concerns the response to endotoxin in protein-deficient rats.

Male Sprague-Dawley rats $(77 \mathrm{~g})$ were fed on diets containing either 80 or $45 \mathrm{~g}$ casein $/ \mathrm{kg}$ for $15 \mathrm{~d}$; at the end of this period body-weights were $185 \mathrm{~g}$ ( $80 \mathrm{~g}$ casein group) and $119 \mathrm{~g}$ ( $45 \mathrm{~g}$ casein group). Six of the twelve rats from each group were then injected with endotoxin (LPS, Escherichia coli lipopolysaccharide serotype o $27 \mathrm{B8}, 3 \mathrm{mg} / \mathrm{kg}$ body-weight), and the remaining rats with saline ( $9 \mathrm{~g}$ sodium chloride/l). A second dose of LPS/saline was given $24 \mathrm{~h}$ after the first, and $6 \mathrm{~h}$ later all rats were killed for measurement of protein synthesis rates, as described by Jepson et al. (1986b).

The $80 \mathrm{~g}$ casein group lost an average $5 \mathrm{~g}$ in body-weight over the $30 \mathrm{~h}$ period after LPS, compared with a $5 \mathrm{~g}$ gain in the $80 \mathrm{~g}$ casein control group. Similarly, the endotoxaemic $45 \mathrm{~g}$ casein group lost $4 \mathrm{~g}$, compared with a $\mathrm{I} g$ gain in weight in the $45 \mathrm{~g}$ casein control group. Food intake of the $80 \mathrm{~g}$ casein group was $23 \mathrm{~g} / \mathrm{d}$ before LPS, and fell by $35 \%$ after LPS. In the LPS $45 \mathrm{~g}$ casein group, intake was reduced by $56 \%$ compared with the untreated control group (intake of $14 \mathrm{~g} / \mathrm{d}$ ). Although rectal temperature was increased after LPS in both dietary groups, no change in $\mathrm{VO}_{2}$ was detected when measured over a $\mathrm{I}$ h period on the day before LPS treatment, and $3-4 \mathrm{~h}$ after each dose of LPS.

The catabolism of muscle protein after LPS was not attenuated in that protein synthesis was reduced by about $40 \%$ in both dietary groups, and degradation was increased by $5 \mathrm{I}$ and $44 \%$ in the 80 and $45 \mathrm{~g}$ casein groups respectively. These changes are similar to those observed in well-fed rats (Jepson et al. $1986 b$ ).

The percentage increases in liver weight and protein and RNA contents were compatible in both dietary groups but the fractional synthesis rate in the $45 \mathrm{~g}$ casein group was increased by only $10 \%$, compared with a normal $37 \%$ increase in the $80 \mathrm{~g}$ casein group. Thus the normal increase in total liver protein synthesis after endotoxin was muted in the $45 \mathrm{~g}$ casein group.

The hormonal response was similar to that seen in well-fed rats, that is hyperinsulinaemia, hypothyroidism and raised plasma corticosterone. However, the latter increase was attenuated in the $45 \mathrm{~g}$ casein group. Corticosterone is thought to be required in optimal amounts for maximal stimulation of acute-phase protein synthesis, and so this may have contributed to the blunted hepatic protein synthesis response to LPS in the $\mathbf{4 5} \mathrm{g}$ casein group.

Jepson, M. M., Millward, D. J., Rothwell, N. J. \& Stock, M. J. (1986a). Proceedings of the Physiological Society 380, 7op.

Jepson, M. M., Pell, J. M., Bates, P. C. \& Millward, D. J. (I 9866 ). Biochemical Fournal 235, 329-336. 
Effect of corticosterone and energy restriction on IGF-I levels, cartilage matrix synthesis and bone growth in the rat. By J. Tirapegui, P. C. Bates, S. D. Dalal, Z. H. Yahya and D. J. MillwaRd, Nutrition Research Unit, London School of Hygiene and Tropical Medicine, 4 St Pancras Way, London NWI $2 P E$

Undernutrition depresses bone growth. Elevated corticosteroids may partially mediate this response since exogenous hormone has a similar effect. The mechanism of this response involves an inhibition of the action of growth factors on bone but it is not clear whether the production of growth factors is also inhibited (Unterman \& Phillips, 1985). We have investigated therefore the responses of bone growth, cartilage matrix synthesis and IGF-I levels to energy restriction and to corticosterone treatment in rats.

We measured tibial growth in length by radiography, ${ }^{35} \mathrm{~S}$-sulphate incorporation in vivo into rib and xiphoid cartilage, and plasma IGF-I and insulin by radioimmunoassay in rats fed ad lib. on a diet containing $120 \mathrm{~g}$ casein $/ \mathrm{kg}$ with or without $100 \mathrm{mg}$ corticosterone/kg per d for $8 \mathrm{~d}$. We also gave separate groups 75, 50 or $25 \%$ of the ad lib. intake with protein concentrations proportionately increased to maintain constant intakes. One group was starved for $4 \mathrm{~d}$. The number of rats per group was six.

Corticosterone completely arrested tibial growth in $2 \mathrm{~d}$, more rapidly than total starvation (3-4 d), whereas the energy restrictions had less marked effects. Tibial length increases over $8 \mathrm{~d}$ were $100,80.4$ and $56 \%$ of the control value for the 75 , 50 and $25 \%$ diets respectively, with cessation of growth only occurring with the $25 \%$ diet after $6 \mathrm{~d}$ of treatment. ${ }^{35} \mathrm{~S}$ incorporation into cartilage was more markedly depressed by the steroid than by any of the restricted diets: $27 \%$ of control into xiphoid compared with 80,80 and $48.5 \%$ in the three energy-restricted groups and $5.4 \%$ of control into rib compared with 56,42 and $13 \%$ of control in the same three groups. IGF-r levels fell in the energy-restricted and steroid-treated groups and were highly significantly correlated with plasma insulin levels, and ${ }^{35} \mathrm{~S}$ incorporation into xiphoid and especially ribs $(r 0.88, n 25$, $P<0.001)$. Values $(\mathrm{U} / \mathrm{ml})$ were 0.276 for the steroid-treated group compared with 0.918 control, $0.46875 \%$ group, $0.57050 \%$ group, $0.21225 \%$ group, although the levels were better maintained than in the starved group (0.068), possibly because of the hyperinsulinemia in the steroid-treated group.

These findings demonstrate that corticosteroids inhibit bone growth by inhibiting production of IGF-I in addition to any inhibitory effect on IGF-I action.

The present study was supported by the Nestle Foundation. The authors are grateful to $\operatorname{Dr} A$. T. Holder for the gift of the labelled IGF-I and antibodies.

Unterman, T. G. \& Phillips, L. S. (1985). Fournal of Clinical Endocrinology 6r, 618-625. 
The activity of cytochrome $c$ oxidase (EC r.9.3.I) in corticosteronetreated rats. By C. J. H. WOODWARD and P. W. EMERY, Department of Food and Nutritional Sciences, King's College (Kensington Campus), Campden Hill Road, London $W_{8}{ }_{7} A H$

Rats treated with corticosterone lose body-weight and lean body mass, and have an unusually high energy expenditure in relation to their size (Woodward \& Emery, 1986). To investigate the basis of these changes, we have measured cytochrome $c$ oxidase activity (CA) as an indicator of the capacity for substrate oxidation in individual tissues.

Male Sprague-Dawley rats of approximately $190 \mathrm{~g}$ were fed on a semi-synthetic diet with or without corticosterone ( $\mathrm{g} / \mathrm{kg}$ ). The animals were killed after $4 \mathrm{~d}$, when the treated group weighed $27 \%$ less than the controls. Crude homogenates were prepared from gastrocnemius muscle and liver, and incubated with digitonin $(5 \mathrm{~g} / \mathrm{l})$ to disrupt mitochondria. CA was then determined in whole muscle and liver by the spectro-photometric method of Wharton \& Tzagoloff (1967). Protein was assayed by a modified Lowry method.
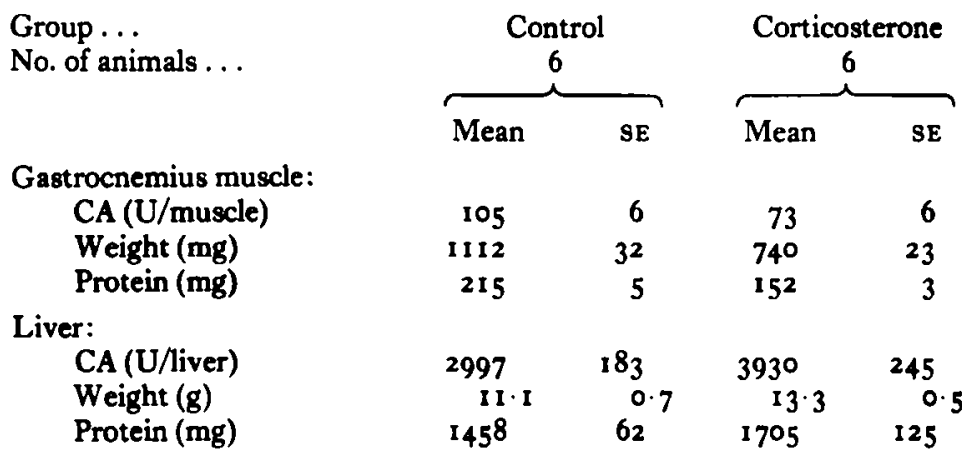

$P<$

$\begin{array}{cc}105 & 6 \\ 1112 & 32 \\ 215 & 5 \\ & \\ 2997 & 183 \\ 11 \cdot 1 & 0 \cdot 7 \\ 1458 & 62\end{array}$

6

23

0.01

0.001

o. 001

3

0.01

0.05

$0 \cdot I$

$P$ values calculated using Student's $t$ test.

$\mathrm{CA}$ weight and protein content in gastrocnemius muscle were all highly significantly reduced by corticosterone $(-31,-34$ and $-29 \%$ respectively; see Table). In contrast, liver showed a highly significant increase in CA $(+31 \%)$, as well as higher tissue weight $(+20 \%)$ and protein content $(+17 \%)$. The increase in hepatic CA indicates a higher capacity for substrate oxidation. Further studies are needed to determine whether energy expenditure is also increased in this tissue.

The present study was supported by the Cancer Research Campaign.

Wharton, D. C. \& Tzagoloff, A. (1967). In Methods in Enzymology, vol. 10, pp. 245-250 [S. P. Colowick and N. O. Kaplan, editors]. New York: Academic Press.

Woodward, C. J. H. \& Emery, P. W. (1986). Proceedings of the Nutrition Society 45, 52A. 
Effect of an anabolic steroid (Durabolin) on body composition of rats treated with insulin. By J. J. CHOO and P. W. EM ERY, Department of Food and Nutritional Sciences, King's College (Kensington Campus), Campden Hill Road, London $W_{8}{ }_{7} A H$

We have previously observed that, under adverse nutritional conditions, the anabolic steroid Durabolin (nandrolone phenylpropionate) tends to suppress fat deposition in rats of both sexes although the anabolic effect on protein deposition is still manifested only in females (Choo \& Emery, 1986). We hypothesized that this effect of anabolic steroids on fat deposition might be through antagonizing the action of insulin. We have therefore investigated the effect of the combined administration of Durabolin and insulin on the body composition of rats of both sexes.

Male (initial weight $200 \mathrm{~g}$ ) and female ( $150 \mathrm{~g}$ ) Sprague-Dawley rats were divided into three groups and provided with food and water ad lib. Two groups of rats received daily subcutaneous injections of Isophane insulin (initial dose $20 \mathrm{U} / \mathrm{kg}$ body-weight increasing to $50 \mathrm{U} / \mathrm{kg}$ ) and one of these groups also received daily subcutaneous injections of Durabolin (a gift from Organon: $2 \mathrm{mg} / \mathrm{kg}$ for females and $4 \mathrm{mg} / \mathrm{kg}$ for males). The third group (control) was given saline and vehicle. All injections were made at $17.00-17.30$ hours. After $12 \mathrm{~d}$, rats were killed by decapitation at $09.00-10.00$ hours.

\begin{tabular}{|c|c|c|c|c|c|c|c|c|c|c|c|}
\hline \multirow[b]{2}{*}{ Treatment } & \multirow[b]{2}{*}{$n$} & \multicolumn{2}{|c|}{$\begin{array}{l}\text { Food intake } \\
(\mathrm{g} / 12 \mathrm{~d})\end{array}$} & \multicolumn{2}{|c|}{$\begin{array}{l}\text { Wt gain } \\
(\mathrm{g} / \mathrm{r} 2 \mathrm{~d})\end{array}$} & \multicolumn{2}{|c|}{$\begin{array}{l}\text { Body protein } \\
\text { (g) }\end{array}$} & \multicolumn{2}{|c|}{$\begin{array}{l}\text { Body fat } \\
\text { (g) }\end{array}$} & \multicolumn{2}{|c|}{$\begin{array}{c}\text { Plasma glucose } \\
\text { (mg/) }\end{array}$} \\
\hline & & Mean & SE & Mean & $\mathrm{SE}$ & Mean & $S E$ & Mean & $S E$ & Mean & SE \\
\hline \multicolumn{12}{|l|}{ Males } \\
\hline Control & 6 & 301 & 9 & I 28 & 5 & $55 \cdot 8$ & I. 6 & $46 \cdot 4$ & 1.7 & I 280 & 40 \\
\hline Insulin & 7 & $3^{8} 7^{\bullet \cdots \bullet}$ & 9 & $15^{\circ \bullet}$ & 5 & $55 \cdot 1$ & I. 6 & $83 \cdot 3^{* \cdots}$ & 5.5 & $370^{\circ}$ & 60 \\
\hline Durabolin & 8 & 345 t†† & 4 & $144^{\dagger}$ & 2 & 55.0 & $1 \cdot 3$ & $63 \cdot 6+t$ & 1.6 & $870 t$ & 200 \\
\hline \multicolumn{12}{|l|}{ Females: } \\
\hline Control & 6 & 206 & 8 & $5^{8}$ & 4 & $34 \cdot 0$ & 0.8 & 34.0 & $1 \cdot 9$ & $155^{\circ}$ & 60 \\
\hline Insulin & 6 & $282^{\bullet \bullet \bullet}$ & I3 & $88^{\bullet \bullet}$ & 4 & 34.5 & $0 \cdot 5$ & $57 \cdot 2^{* 10}$ & $3 \cdot 3$ & $580^{\bullet \cdots \bullet}$ & 120 \\
\hline Durabolin & 8 & 271 & I0 & $107 t t$ & 4 & $40.9 t^{+t}$ & 0.8 & $47.0 t$ & $2 \cdot 2$ & $12000 t$ & 150 \\
\hline
\end{tabular}

Mean values were significantly different: insulin $v$. control $(\bullet P<0.05, \cdots P<0.01, \cdots P<0.001)$; Durabolin $v$. insulin $(† P<0.05, \uparrow \dagger P<0.01, \uparrow \uparrow \uparrow P<0.001)$.

Administration of exogenous insulin caused marked hyperphagia, presumably because of hypoglycaemia. The extra food ingested was used very efficiently for fat synthesis. However, exogenous insulin by itself had no effect on protein deposition. Additional administration of Durabolin partially alleviated the hypoglycaemia and reduced much of the fat deposition. It also increased protein deposition in the female rats but not in the males.

Thus it appears that anabolic steroids act on fat metabolism by antagonizing the action of insulin, whereas their action on protein metabolism appears to be independent of insulin.

Supported by ISFE (Switzerland) and the Cancer Research Campaign.

Choo, J. J. \& Emery, P. W. (1986). Proceedings of the Nutrition Society 45, 109A. 
Effect of high-fibre diets on faecal DNA and mucosal cell proliferation in the rat. By Sanoja Sandaradura ${ }^{1}$, A. E. Bender ${ }^{1}$ and P. B. Gahan ${ }^{2}$, Departments of 'Nutrition and 'Biology, King's College (Kensington Campus), Campden Hill Road, London $W_{7}{ }_{7} A H$

The low digestibility of legume protein has been explained as being largely due to an increased excretion of endogenous nitrogen resulting from increased division of the mucosal cells in the small intestine (Sandaradura \& Bender, r 984 ).

Although legumes are known to contain a high proportion (0.25) of dietary fibre, the effect of high-fibre diets on faecal DNA and cell proliferation has not been extensively studied. However, evidence is slowly accumulating that dietary fibre may be partly involved in the above mentioned phenomena.

Thirty male Lister Hooded weanling rats were divided into five groups of six. Animals were fed ad lib. for $14 \mathrm{~d}$ on a casein diet (200 g protein $/ \mathrm{kg}$ diet) or high-fibre diets containing cooked whole white or red kidney beans (Phaseolus vulgaris), coarse wheat bran (each containing $200 \mathrm{~g}$ protein/kg diet) or laboratory stock diet ( $190 \mathrm{~g}$ protein $/ \mathrm{kg}$ diet). The fibre contents of the diets were $65,167,167$, 160 and $153 \mathrm{~g} / \mathrm{kg}$ respectively. Food intake, faecal nitrogen and DNA were measured. On the $14^{\text {th }}$ day the rats were injected intraperitoneally with colchicine (I $\mathrm{mg} / \mathrm{kg}$ body-weight). Pieces of intestine, each $20 \mathrm{~mm}$ in length, were cut approximately $200 \mathrm{~mm}$ from the pylorus end, slit open and fixed in formal-saline before embedding, sectioned at $5 \mu \mathrm{m}$ thickness and stained with Feulgen's reagent. Metaphases in arrested cells from twenty crypts per animal were counted.

\begin{tabular}{|c|c|c|c|c|c|c|c|c|}
\hline \multirow[b]{3}{*}{ Dict } & \multicolumn{6}{|c|}{ Faeces } & \multirow{2}{*}{\multicolumn{2}{|c|}{$\overbrace{\begin{array}{c}\text { Metaphases/ } \\
\text { crypt }\end{array}}^{\text {Intestine }}$}} \\
\hline & \multicolumn{2}{|c|}{$\begin{array}{l}\text { Dry wt } \\
(\mathrm{g} / \mathrm{kg})\end{array}$} & \multicolumn{2}{|c|}{$\underset{\text { (mg/g food) }}{\mathrm{N}}$} & \multicolumn{2}{|c|}{$\begin{array}{c}\text { DNA } \\
\text { (mg/g food) }\end{array}$} & & \\
\hline & Mean & SEM & Mean & SEM & Mean & SEM & Mean & SEM \\
\hline Casein & 166 & 2 & $7 \cdot 0$ & 0.3 & 0.75 & 0.01 & $12 \cdot 0$ & 0.7 \\
\hline White bean & $227^{\bullet \otimes a}$ & 2 & $10.0 * 2$ & 0.3 & $1.82 \cdots a$ & 0.02 & $22 \cdot 0^{\circ \bullet}$ & 0.7 \\
\hline Red bean & $234^{\bullet 02}$ & 3 & $10 \cdot 7^{\bullet 022}$ & 0.3 & $1 \cdot 82^{\bullet \bullet a}$ & 0.03 & $20 \cdot 0^{\circ 0}$ & 0.5 \\
\hline Stock & $293^{\bullet \bullet b}$ & I0 & $13 \cdot 3^{\cdots b b}$ & 0.4 & $1 \cdot 90^{\circ e a}$ & 0.06 & $23.0^{\circ 0}$ & 0.4 \\
\hline Wheat bran & $259^{\bullet \bullet a}$ & 2 & II $\cdot 5^{\bullet-2}$ & 0.3 & $1 \cdot 44^{e e b}$ & 0.01 & $21 \cdot 0^{00}$ & 0.5 \\
\hline
\end{tabular}

Significantly different from control (casein) diet: $\bullet \bullet P<0 \cdot 01$.

a,bValues within a column with unlike superscript letters were significantly different: $P<0.05$.

Rats fed on red or white kidney beans, wheat bran or the stock diet excreted nearly twice as much $\mathrm{N}$ and DNA in the faeces as those fed on the casein diet, while the number of cells which underwent division were increased twofold. It is not clear from these results how much faecal DNA comes from desquamated mucosal cells. The overall effect appears, at least partially, to be due to dietary fibre.

The study was supported by a grant from the Nestlé Foundation, Switzerland.

Sandaradura, S. S. \& Bender, A. E. (1984). Proceedings of the Nutrition Society 43, 89A. 
Evaluating a district food and health policy: the Bloomsbury experience. By Joyce Treuherz, Clinical Nutrition Unit, Department of Surgery, University College School of Medicine, Rayne Institute, University Street, London WCIE 67$\}$ and ANDREw Tomkins, Department of Human Nutrition, London School of Hygiene and Tropical Medicine, Keppel Street, London $W C_{1} E_{7} H T$

Bloomsbury, London, was only the second health district to develop a food and health policy (FHP). It was designed to increase provision of food in line with the policy and to raise awareness, both among district staff and patients, and in the wider community, about the importance of preventing chronic disease through better dietary practice. The Bloomsbury FHP's goals were similar to those of the National Advisory Committee on Nutrition Education (1983).

A pilot implementation of the FHP was carried out at two hospitals. An intensive intervention consisting of a launch day and considerable publicity with education and training of catering staff was focused at the Middlesex Hospital, London. This was contrasted with minimal intervention at University College Hospital, London. Staff-meal choices (about I 200 canteen meals daily) were monitored for 10 months. Recording sheets were used which classified main meals into predetermined categories. Analysis of each category was a percentage of total meals chosen. Baseline and follow-up nutritional analysis of the proximal nutrients (as percentage of total energy) plus dietary fibre ( $g$ ) were calculated in a sub-sample using a computer programmed with McCance and Widdowson's food tables (Paul \& Southgate, 1978). A summary of results is given in the Table.

\begin{tabular}{|c|c|c|c|c|}
\hline \multirow[t]{2}{*}{ Hospital... } & \multicolumn{2}{|c|}{ Middlesex } & \multicolumn{2}{|c|}{ University College } \\
\hline & Baseline & Follow-up & Baseline & Follow-up \\
\hline \multicolumn{5}{|l|}{$\begin{array}{l}\text { Classification of complete meal } \\
\text { choices (\% of total) }\end{array}$} \\
\hline No. of meals & 19434 & 19917 & 34734 & 33747 \\
\hline Vegetarian (lacto-ovo) & 4 & 15 & 20 & 20 \\
\hline Salads & 14 & 12 & 10 & 8 \\
\hline Fish & II & 13 & 9 & 13 \\
\hline Poultry & 8 & 12 & 7 & 7 \\
\hline Red meat and eggs & 63 & 48 & 54 & 52 \\
\hline \multicolumn{5}{|l|}{$\begin{array}{l}\text { Composition of a sub-sample of } \\
\text { meals chosen: }\end{array}$} \\
\hline No. of meals & 47 & 70 & 35 & 80 \\
\hline Fat $(\%$ of energy) & 45 & 47 & 57 & 44 \\
\hline Protein (\% of energy) & 19 & I 5 & 20 & 16 \\
\hline Carbohydrate (\% of energy) & 36 & 38 & 25 & $4 \mathrm{I}$ \\
\hline Dietary fibre (g) & $6 \cdot 2$ & 9.5 & 6 & 7 \\
\hline
\end{tabular}

We suggest that successful implementation of a district FHP is much more difficult than is commonly appreciated and we will discuss some of the constraints that were identified.

National Advisory Committee on Nutrition Education (1983). A Discussion Paper on Proposals for Nutritional Guidelines for Health Education in Britain. London: Health Education Council.

Paul, A. A. \& Southgate, D. A. T. (1978). McCance and Widdowson's The Composition of Foods. London: H.M. Stationery Office. 
Nutrient intakes in three English towns. By Janet CaDe, D. J. P. Barker, JULIE MORRIS and BARRIE MARGETTS, MRC Environmental Epidemiology Unit, University of Southampton, Southampton General Hospital, Southampton $\mathrm{SO}_{9}{ }_{4} \mathrm{XY}$

Attempts to relate the geographical distribution of diseases in England to dietary intakes have been limited by the lack of information on sex- and age-specific dietary intakes. In the present study $24 \mathrm{~h}$ dietary records using household measures were collected from a 5-year age-stratified (35-54 years) sample of subjects from Ipswich ( $37 \mathrm{I}$ men, 406 women), Wakefield ( 375 men, 420 women) and Stoke-on-Trent (398 men, 440 women). These towns had different socio-economic status, geographical locations and disease rates.

Dietary records were kept on a specified day such that there was an even distribution of days of the week and season in each town. Household portions were converted to gram weights and nutrient levels calculated.

Table 1. Daily nutrient intakes in men from three English towns

(Adjusted mean values with $95 \%$ confidence intervals (CI))
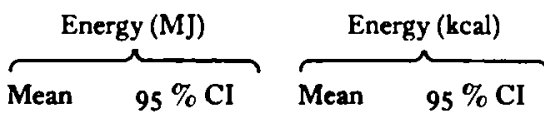

Ipswich $10.70 \quad(10.05,11 \cdot 37) 2556 \quad(2401,2717)$

Wakefield $9.90^{2}(9.28,10.53) \quad 23^{6} 5^{2} \quad(2217,2517)$

Stoke $\quad 11 \cdot 17^{b} \quad(10.53,11 \cdot 83) \quad 2670^{b} \quad(2517,2827)$

Variance

ratio

$P<$

3.64

0.05

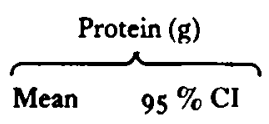

$84 \cdot 1 \quad(78 \cdot 8,89 \cdot 7)$

$83 \cdot 1 \quad(77 \cdot 8,88 \cdot 5)$

$92 \cdot 1 \quad(86 \cdot 7 \cdot 97 \cdot 7)$

$3 \cdot 19$

0.05
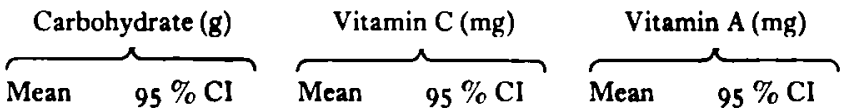

Ipswich

Wakefield $260 \cdot 5^{\mathrm{b}} \quad(242 \cdot 5,279 \cdot 1)$

Stoke

$308 \cdot 4^{2}$

$(289 \cdot 1,328 \cdot 3)$

$60 \cdot 1^{2}$

$(51 \cdot 6,69 \cdot 3)$

$(35 \cdot 8,52 \cdot 2)$

$\left(40 \cdot 6,5^{6 \cdot 7}\right)$

$953^{2} \quad(801,1136)$

$643^{\mathrm{b}} \quad(531,779)$

Variance

ratio

P<

$$
6 \cdot 22
$$

$4 \cdot 70$

0.01

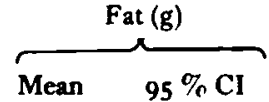

$106.9 \quad(98.8,115 \cdot 2)$

$94 \cdot 6 \quad(87 \cdot 1,102 \cdot 3)$

$107.6 \quad(99 \cdot 7,1 \pm 5.8)$

a,b Values with unlike superscript letters were significantly different (LSD test): $P<0.01$.

The dietary fibre, vitamin $C$ and $\beta$-carotene intakes of women were significantly different between the towns. For men, proximate nutrient intakes were highest in Stoke whereas vitamin $C$ and vitamin $A$ levels were highest in Ipswich (Table I). Analysis of variance with adjustments for covariates (such as body mass index, activity) were used to test for differences between towns. In addition to those nutrients shown in the Table, fibre, retinol, $\beta$-carotene and percentage energy from fat were significantly different between towns, with Wakefield generally having the lowest mean levels. 
Eating patterns of Afro-Caribbean mothers in Birmingham. By J. R. KEMM, J. Douglas and V. Sylvester, Department of Social Medicine, University of Birmingham, Birmingham $B{ }_{1} 2$ TY

The sampling frame for this survey has been described previously (Kemm et al. I986). In three studies mothers of children born in specified weeks were interviewed to obtain information on infant feeding practice and the food consumption and practices of the mother. In the latter two studies the mothers were also asked to keep a food diary quantified in household measures for $\mathrm{I}$ week.

In the last two studies, seventy-eight mothers were asked 'How often do you eat traditional Afro-Caribbean meals?'. 'Thirty-one per cent said they did so nearly every day, $13 \%$ four to five times a week, $46 \%$ one to three times a week and only $10 \%$ less than once a week. Those who ate traditional meals frequently $\left(>_{3}\right.$ times a week) were older (mean 26.6 (SD $5.4, n 34$ ) v. 24.4 (SD $3.6, n 44$ ) years, $P<0.05$ ) and more likely to have other children $(27 / 34$ v. $24 / 44 ; P<0.05)$ than others. Mothers were asked about avoiding certain foods (those prohibited in a strict I-tal diet). A large number $(43 / 102)$ avoided pork and $15 \%$ avoided other meats. Nearly half $(43 /$ ro2 $)$ avoided alcohol.

Seventy-two mothers completed food diaries covering $505 \mathrm{~d}$. The number of portions of various foods consumed per week were as follows: poultry $1 \cdot 8$, meat products and pies $2 \cdot 2$, other meats $4 \cdot 0$, fish $2 \cdot 1$, vegetables and salads 10.6, fresh fruit $1 \cdot 0$, bread 12.8 (slices), potatoes 4.2 , rice 3.2 , dumplings 1.6 and exotic staples such as yam $\mathbf{I} \cdot 0$. Much of the meat and vegetables were consumed as 'soups' or other one-pot meals. Afro-Caribbean vegetables made a significant contribution (3.4 portions/week). Conversion of these values to weight consumed using guesstimated portion sizes allows comparison with the general population (Ministry of Agriculture, Fisheries and Food, 1986). This comparison suggests that Afro-Caribbeans were consuming more fish, but less bread and potatoes which were partially replaced as carbohydrate sources by dumplings, yam and other Afro-Caribbean foods.

We did not find evidence of widespread consumption of the very restrictive dietaries described by Springer \& Thomas ( 1983 ). The study reminds those working in health promotion that messages based on 'usual Caucasian patterns' may appear irrelevant to many groups in the community.

The present study was supported by Birmingham Inner City Partnership.

Kemm, J. R., Douglas, J. \& Sylvester, V. (1986). Proceedings of the Nutrition Society 45, $87 \mathrm{~A}$.

Ministry of Agriculture, Fisheries and Food (1986). Household Food Consumption and Expenditure 1985. London: H.M. Stationery Office.

Springer, L. \& Thomas, J. (1983). Human Nutrition: Applied Nutrition 37A, $120-127$. 
The effect of soya-bean protein on intestinal morphology, absorption and enzyme activity in gnotobiotic pigs at 3 weeks of age. By $B$. RATClifFE", AFRC Institute of Food Research, Shinfield, Reading RG2 gAT, M. W. SмITH, AFRC Institute of Animal Physiology and Genetics, Cambridge $C B 24 A T$, and B. G. Miller and F. J. Bourne, Department of Veterinary Medicine, University of Bristol, Langford, Bristol $B S{ }_{18}{ }_{7} D U$

Marked morphological changes occur in the intestines of pigs after weaning and these may be involved in the aetiology of post-weaning diarrhoea. Various authors have suggested that these changes may result from weaning per se, viral infection, bacterial proliferation, or a direct effect of a dietary change associated with weaning. To examine the effect of the latter in isolation, a study was made with gnotobiotic pigs.

Sixteen gnotobiotic pigs (in two separate trials), obtained and reared as described by Ratcliffe \& Fordham (1987), were maintained for 3 weeks on a liquid diet (control diet) based on bovine milk ( $\mathrm{g} / \mathrm{kg}$ dry matter: fat 120 , carbohydrate 470 , protein 320 ). On the ist day post natum, each pig received a 'priming' dose of soya-bean protein as a supplement of $4 \mathrm{~g}$ of soya-bean flour (Protosoya ${ }^{(8)}$; Spillers Premier Products Ltd, Cambridge; an alcohol-extracted, heat-treated soya-bean flour) mixed in with the liquid feed. At 3 weeks of age, four pigs were changed to the treatment diet which had the same proximate composition as the control diet but $66 \%$ of the protein was provided from soya bean. After $5 \mathrm{~d}$ the pigs were killed and samples were taken at the mid-point of the small intestine for histological and biochemical analysis.

Analyses of variance of the two trials showed that the presence of soya-bean flour in the diet caused a significant increase in mean crypt depth (158.0 0 . $171 \cdot 9$ $\mu \mathrm{m} ; P<0.02$ ) with no significant changes in mean villus height (1020 v. 1023 $\mu \mathrm{m}$ ). The pattern of alanine and lysine transport remained unchanged, as did the activities ( $\mu \mathrm{mol}$ substrate hydrolysed/mg protein per $\mathrm{h}$ in homogenates) of sucrose $\alpha$-glucosidase ( $E C$ 3.2.1.48) (8.9 (SD 0.7) v. 11 .3 (SD 0.8)), $\alpha$-glucosidase (maltase; $E C$ 3.2.1.20) (10.2 (SD 0.9) v. 9.3 (SD 0.4)) and lactase (EC 3.2.1.108) (8. I (SD 0.6) ข. $7 \cdot 8(\mathrm{SD} 0.2))$.

Comparisons with the conventionally reared pigs of Miller et al. (1986) showed gnotobiotic pigs to have longer villi (ro20 $0.681 \mu \mathrm{m})$, similar crypts $(\mathrm{r} 58.0 \mathrm{v}$. 16 $\mathrm{I}$ $\mu \mathrm{m}$ ) and approximately double the activities for sucrose a-glucosidase $(8.9 v .5 .6)$, $\alpha$-glucosidase ( 10.2 v. 3.5) and lactase (8.1 $v .5 .0)$. Alanine and lysine also were absorbed further down the villi in gnotobiotic pigs (600 v. $300 \mu \mathrm{m}$ from the villus tip).

These results demonstrate a small selective effect of soya-bean flour on crypt hyperplasia in gnotobiotic pigs. This response could be important in the initiation of the changes seen in conventional pigs after weaning.

Miller, B. G., James, P. S., Smith, M. W. \& Bourne, F. J. (1986). Fournal of Agricultural Science, Cambridge 107, 579-589.

Ratcliffe, B. \& Fordham, J. P. (1987). Laboratory Animals 21, 53-59.

-Present address: The Polytechnic of North London, Holloway Road, London. 
Qualitative and quantitative intestinal absorption and hepatic metabolism in conscious pigs. I. Glucose and amino nitrogen. By C. Simoes Nunes, A. Rerat, P. Vaugelade and P. Vaissade, Laboratoire de Physiologie de la Nutrition, INRA-CNRZ ${ }_{78} 350$ fouy-en-fosas, France

A new technique for simultaneous measurement of intestinal absorption and hepatic balance (Simoes Nunes et al. 1984), based on catheterization of the portal vein, carotid artery and upper hepatic vein as well as on use of electromagnetic flow probes around the portal vein and hepatic artery, was applied to five growing pigs (66.8 (SE I . 7) kg). Each animal was submitted to a duodenal perfusion of I IO $\mathrm{g}$ milk small peptides (MSP) or the same amount and pattern of free amino acids (FAA). Each perfusion, which also contained $440 \mathrm{~g}$ maltose-dextrine, was made for $\mathrm{I} h$ after $\mathrm{I} 8 \mathrm{~h}$ of fasting. The period of observation lasted $8 \mathrm{~h}$. The continuously recorded hepatic blood flow rate was 2936 (SE I99) $\mathrm{ml} / \mathrm{min}\left(n_{10}\right)$ of which $85.8 \%$ proceeded from the portal vein.

The amount of amino nitrogen absorbed during the first $2 \mathrm{~h}$ was higher $(\mathrm{r} 35 \%$, $P<0.05)$ after MSP than after FAA perfusion and lower during the next $2 \mathrm{~h}(56 \%$, $P<0.05)$. The cumulated absorbed quantities $(8 \mathrm{~h})$ were very similar for the two types of perfusions (68\% of the perfused quantity for both). The hepatic $\mathrm{N}$ flux patterns were similar to those of the absorption. The hepatic uptake of $\mathrm{N}$ was higher at the beginning of the perfusions.

The absorbed amount of glucose was larger after MSP perfusion with a maximum during the and hour; it represented 76 and $84 \%$ respectively of the perfused quantities of FAA and MSP throughout the experiment. The pattern of the hepatic glucose flux was similar to that of the absorption. During the first $5 \mathrm{~h}$ there was a large uptake of glucose by the liver followed by a slow release during the last $3 \mathrm{~h}(6.4 \mathrm{~g} / \mathrm{h}$ during the 8 th hour $)$.

According to these results, our technique seems to be well fitted for a simultaneous study of intestinal absorption and hepatic metabolism in vivo. It was shown that $\mathrm{N}$ is more rapidly absorbed when perfused into the duodenum in the form of small peptides than in the free form, at least during the first hours of digestion. It also appeared that the in vivo absorption of glucose is in competition with that of FAA and small peptides.

Simoes Nunes, C., Rérat, A., Vaugelade, P. \& Vaissade, P. (1984). Diabète et Métabolisme 10, 349 . 
Qualitative and quantitative intestinal absorption and hepatic metabolism in conscious pigs. 2. Lactate, pyruvate, ammonia-nitrogen and urea. A. Rerat, C. Simoes Nunes, P. VAugelade and P. Vaissade, Laboratoire de Physiologie de la Nutrition, INRA-CNRZ $7835^{\circ}$ fouy-en-fosas, France

The absorption and hepatic metabolism of lactate, pyruvate, ammonia-nitrogen $\left(\mathrm{NH}_{3}-\mathrm{N}\right)$ and urea were studied in conscious pigs using the same technique and experimental conditions as those described previously (Simoes Nunes et al. 1987).

The appearance of lactate was larger $(P<0.05)$ after duodenal perfusion of free amino acids (FAA) than after that of milk small peptides (MSP) (14.0 (SE 3.6) and $5.2(S E 0.6) \mathrm{g} / 8 \mathrm{~h}$ ) respectively while the hepatic input was the same (MSP 20.7 (SE 2.6), FAA $21.9(\mathrm{SE} \mathrm{2.2)} \mathrm{g} / \mathrm{h})$. The hepatic lactate production was higher after MSP than after FAA perfusion (I I.6 (SE 3.0) v. 3.9 (SE 3.7) $\mathrm{g} / 8 \mathrm{~h}$ ).

Pyruvate appearance in portal blood was highly variable and normally low; the range of hepatic output and input values after MSP perfusion were similar to those recorded after FAA perfusion, but the output always exceeded the input, accounting for a continuous liver pyruvate production (MSP 3.14 (SE 0.9), FAA $3.99(\mathrm{SE} \mathrm{I} \cdot 2) \mathrm{g} / 8 \mathrm{~h}$ ).

The absorption of $\mathrm{NH}_{3}-\mathrm{N}$ was rather large throughout the 8-h experiment (MSP r.67 (SE 0.1 I), FAA I. 26 (SE 0.15) g/8 h). All absorbed $\mathrm{NH}_{3}-\mathrm{N}$ was taken up by the liver.

The absorption of urea was small after both perfusions. The hepatic fluxes were not significantly different (input g/8 h: MSP 243.0 (SE 13. 5), FAA 275. 5 (SE 27. I); output $\mathrm{g} / 8 \mathrm{~h}$ : MSP $246 \cdot 2$ (SE I $3 \cdot 8$ ), FAA $284 \cdot 0$ (SE 24. I)). The urea production was not significantly different for the whole period (MSP 3.22 (SE 3.4), FAA 8.42 (SE 4.7$) \mathrm{g} / 8 \mathrm{~h}$ ) but was larger in the case of FAA during the last hours of observation.

In conclusion, duodenal perfusion of MSP in growing pigs as compared with that of FAA led to (a) a larger $\mathrm{NH}_{3}-\mathrm{N}$ absorption and a smaller urea production by the liver, (b) a higher and earlier production of lactate in the liver linked to an earlier glucose absorption and (c) similar pyruvate production.

Simoes Nunes, C., Rérat, A., Vaugelade, P. \& Vaissade, P. (1987). Proceedings of the Nutrition Society 46, 102A. 
Absorption kinetics of amino acids from amino acid mixtures of the same composition perfused into the small intestine in the free form or as enzymic milk protein hydrolysates in conscious pigs. By A. RERAT and C. Simoes Nunes, Laboratoire de Physiologie de la Nutrition, INRA-CNRZ, $7835^{\circ}$ fouy-en-fosas, France, and P. MENDY and L. ROGER, U.R.D. SOPHARGA, 5 rue Bellini, 92806 Puteaux, France

It is generally believed that the intestinal transport systems of oligopeptides are independent of those of amino acids, leading to less competition between amino acids for sites of absorption and rendering the latter more efficient. An experiment was carried out in conscious pigs to verify these phenomena and estimate their nutritional importance. The method used is based on the simultaneous measurement of portal blood flow rate and porto-arterial concentration differences (amino nitrogen, amino acids) accounting for the gastrointestinal blood enrichment during digestion (Rérat et al. 1980). It was used to determine the quantitative kinetics of appearance of these nutrients in the portal vein of six pigs $(57.7$ (SE $0.99) \mathrm{kg}$ ) fitted with permanent cannulas in the portal vein, carotid artery and duodenum and an electromagnetic flow probe around the portal vein. The animals received at $3^{-\mathrm{d}}$ intervals duodenal perfusions of a solution containing $110 \mathrm{~g}$ milk small peptides (MSP) obtained by mild hydrolysis of milk protein, or $110 \mathrm{~g}$ free amino acids (FAA) of the same composition (Rerat et al. 1985).

Total amounts of amino nitrogen appearing in the portal vein in $5 \mathrm{~h}$ were $60 \%$ higher after MSP perfusion, the differences with FAA being only significant during the first $90 \mathrm{~min}$. During this period, the amounts of amino acids in the portal vein after MSP perfusion were significantly higher for some of them (histidine, lysine, phenylalanine, threonine, arginine, tyrosine, serine and alanine) and significantly lower for methionine than those recorded after FAA perfusion; after $5 \mathrm{~h}$, concentrations of leucine, valine and glutamic acid were also higher. The composition of absorbed mixtures was changed relative to that of the perfused ones. One hour after MSP treatment, the absorbed mixture contained more phenylalanine, leucine, arginine, tyrosine, serine, proline and alanine, and less methionine, threonine, histidine, glutamic acid and aspartic acid than the perfused mixture. One hour after FAA treatment, the blood enrichment concerned leucine, isoleucine, valine, methionine, proline, glycine and alanine and the impoverishment of threonine, histidine, lysine, glutamic acid and serine. The same trends were observed after $5 \mathrm{~h}$, but the differences were much more reduced between the composition of the absorbed and perfused mixture after MSP perfusion.

Rèrat, A., Simoes Nunes, C., Vaugelade, P. \& Vaissade, P. (1985). Compte Rendu de l'Academie des Sciences, Paris 300, 293.

Rérat, A., Vaugelade, P. \& Villiers, P. A. (1980). In Current Concepts of Digestion and Absorption in Pigs, Technical Bulletin no. 3, p. 177. [G. Low and I. G. Partridge, editors]. Reading/Ayr: National Institute for Research in Dairying/Hannah Research Institute. 